\title{
Meningkatkan Kematangan Karier Peserta Didik SMA dengan Pelatihan Reach Your Dreams dan Konseling Karier
}

\author{
Ahmad Saifuddin ${ }^{1}$, Lisnawati Ruhaena ${ }^{2}$, Wiwien Dinar Pratisti ${ }^{3}$ \\ 1,2,3Magister Psikologi Profesi Universitas Muhammadiyah Surakarta
}

\begin{abstract}
Career maturity is a condition that needed to choice the program in higher level study. Henceforth, the low level of career maturity in senior high school student has to be solved with the comprehensive intervention as soon as possible. The purpose of this research is to know the effectivity of Reach Your Dreams Training and career counseling for improving career maturity in senior high school student. This research used Solomon Six Group Design. Subjects of this research are 42 senior high school students with average level of career maturity who are divided into two groups given Reach Your Dreams Training, two groups given career counseling, and two control groups. According to the result, the conclusion of this research is Reach Your Dreams Training and Counseling Career can improve career maturity level in senior high school students effectively. It is caused by the effect of Reach Your Dreams Training and career counseling, and not caused by the effect of pretest.
\end{abstract}

Keywords: career counseling; career maturity; Reach Your Dreams training

Abstrak. Kematangan karier merupakan suatu kondisi yang dibutuhkan untuk mampu memilih jurusan studi lanjut dan karier yang sesuai dengan potensi individu, sehingga permasalahan kematangan karier harus segera diatasi. Penelitian ini bertujuan untuk mengetahui efektivitas pelatihan Reach Your Dreams dan konseling karier dalam meningkatkan kematangan karier peserta didik. Penelitian ini menggunakan desain Solomon Six Group Design. Subjek penelitian sebanyak 42 peserta didik dengan tingkat kematangan karier sedang, dibagi menjadi dua kelompok pelatihan Reach Your Dreams (dua kelompok konseling karier, dan dua kelompok kontrol). Berdasarkan hasil analisis data dapat disimpulkan bahwa pelatihan Reach Your Dreams dan konseling karier efektif meningkatkan kematangan karier. Peningkatan tersebut karena efek dari perlakuan, bukan efek faktor belajar dari pretest.

Kata kunci: kematangan karier; konseling karier; pelatihan Reach Your Dreams

Sejak masa remaja seseorang sudah dihadapkan pada pemilihan dan persiapan diri untuk menjalankan suatu pekerjaan atau karier karena pekerjaan atau karier seseorang menentukan berbagai hal dalam kehidupan (Hurlock,

\footnotetext{
${ }^{1}$ Korespondensi mengenai isi artikel ini dapat dilakukan melalui:

ahmad saifuddin48@yahoo.com,

${ }^{2}$ lisnawati.ruhaena@ums.ac.id,

${ }^{3}$ wiwien.pratisti@ums.ac.id
}

1980). Havighurst (1984) menyatakan bahwa memilih dan mempersiapkan karier atau pekerjaan merupakan salah satu tugas perkembangan yang harus dilakukan oleh setiap remaja. Super, Crites, Hummel, Moser, Overstreet, \& Warnath (1957) mengatakan perkembangan karier pada masa sekolah menengah sebagai tahap eksplorasi yang dimulai pada usia 15 sampai 24 tahun. Pada tahap ini remaja mengembangkan 
kesadaran terhadap dirinya dan dunia kerja, dan mulai mencoba peran-peran baru, maka dalam hal ini diperlukan kematangan karier. Brooks (Brown \& Brooks, 1990) mengemukakan bahwa kematangan karier sebagai kesiapan kognitif dan afektif dari individu remaja untuk mengatasi tugas-tugas perkembangan yang dihadapkan kepadanya di masa selanjutnya.

Santrock (2003) menyatakan bahwa remaja seringkali memandang eksplorasi karier dan pengambilan keputusan sekolah lanjut dengan disertai perasaan bimbang, ragu-ragu, ketidakpastian, dan stres. Hal ini didukung oleh penelitian yang dilakukan oleh Triana (Setyawati, 2005) yang menunjukkan bahwa $45 \%$ siswa Sekolah Menengah Atas belum memiliki perencanaan mengenai karier yang akan dipilihnya, karena masih mengalami keraguan. Data angket dari penelitian awal yang dilakukan peneliti menunjukkan 30,719\% peserta didik belum memiliki gambaran masa depan secara jelas.

Beberapa penelitian berusaha untuk melakukan intervensi untuk meningkatkan kematangan karier, antara lain Hidayat (2014), Ardiyanti \& Alsa (2015), Avati \& Cahyadi (2010), dan Iffah (2012). Kematangan karier juga dapat ditingkatkan dengan konseling karier. Hal ini ditunjukkan pada penelitian Ardana, Dharsana, \& Suranata (2014) Arthur \& McMahon (2005), Koivisto (2010). Para peneliti tersebut menjelaskan mengenai berbagai teknik dan program dalam memberikan konseling karier.

Peneliti mencoba memodifikasi penelitian-penelitian terdahulu, khususnya pelatihan Perencanaan Lanjut Studi atau PLANS (Ardiyanti \& Alsa, 2015; Hidayat, 2014) dan konseling karier Holland dengan teknik modeling (Ardana,
Dharsana, \& Suranata, 2014). Modifikasi tersebut meliputi melengkapi materi yang belum disajikan dalam pelatihan PLANS (untuk pelatihan PLANS) sehingga tercipta pelatihan yang bernama Reach Your Dreams. Pelatihan kematangan karier Reach Your Dreams ini disusun berdasarkan modifikasi dari pelatihan "PLANS" atau Perencanaan Lanjut Studi yang diciptakan oleh Ardiyanti \& Alsa (2015) dan Hidayat (2014). Pelatihan "PLANS" berpedoman pada teori perencanaan karier Jaffe dan Scott (1991). Jaffe dan Scott (1991) menjelaskan bahwa perencanaan karier memiliki tahapan menilai diri sendiri, mengeksplorasi peluang, menyusun rencana karier, implementasi, dan evaluasi. Berdasarkan tahapan perencanaan karier tersebut, pada pelatihan Reach Your Dreams, terdapat enam sesi pelatihan. Enam sesi pelatihan tersebut yaitu analisis diri (tipe kepribadian karier), memahami lingkungan karier, wawasan program studi dan karier, tetapkan tujuanmu, do it now, dan evaluasi.

Beberapa hipotesis yang diajukan dalam penelitian ini yaitu: (1) pelatihan "Reach Your Dreams" efektif meningkatkan kematangan karier peserta didik; (2) konseling karier efektif meningkatkan kematangan karier peserta didik; (3) tidak terdapat perbedaan tingkat kematangan karier antara kelompok yang diberikan pelatihan "Reach Your Dreams" dengan kelompok yang diberikan konseling karier.

\section{Metode}

Penelitian ini menggunakan pendekatan eksperimen dengan desain Solomon atau Randomized Solomon Six Group Design. Desain eksperimen Solomon merupakan gabungan desain eksperimen pascates serta desain eksperimen pra tes dan 
pascates (Latipun, 2010; Hadi, 2015; Kerlinger, 1990; Cozby, 2009). Penelitian ini diterapkan kepada 42 peserta didik SMA Negeri 1 Karanganom kelas X dan XI yang dibagi menjadi enam kelompok dan menggunakan dua jenis intervensi yaitu pelatihan "Reach Your Dreams" dan konseling karier.

Secara skematis, desain eksperimen Solomon dapat digambarkan seperti berikut:

Tabel 1.

Rancangan eksperimen

R \begin{tabular}{ccccc} 
KE 1 & $\mathrm{O}_{1}$ & $\mathrm{X}_{1}$ & $\mathrm{O}_{2}$ & $\mathrm{O}_{3}$ \\
\hline KE 2 & $\mathrm{O}_{1}$ & $\mathrm{X}_{2}$ & $\mathrm{O}_{2}$ & $\mathrm{O}_{3}$ \\
\hline KK 3 & $\mathrm{O}_{1}$ & $(----)$ & $\mathrm{O}_{2}$ & $\mathrm{O}_{3}$ \\
\hline KE 4 & --- & $\mathrm{X}_{1}$ & $\mathrm{O}_{2}$ & $\mathrm{O}_{3}$ \\
\hline KE 5 & --- & $\mathrm{X}_{2}$ & $\mathrm{O}_{2}$ & $\mathrm{O}_{3}$ \\
\hline KK 6 & --- & $(---)$ & $\mathrm{O}_{2}$ & $\mathrm{O}_{3}$ \\
\hline
\end{tabular}

Keterangan :

KE 1 : Kelompok eksperimen dengan pelatihan Reach Your Dreams

KE 2 : Kelompok eksperimen dengan konseling karier

KK 3 : Kelompok kontrol

KE 4 : Kelompok eksperimen dengan pelatihan Reach Your Dreams

KE 5 : Kelompok eksperimen dengan konseling karier

KE 6 : Kelompok kontrol

$\mathrm{R}$ : Random assignment

$\mathrm{X}_{1} \quad$ : Pelatihan Reach Your Dreams

$\mathrm{X}_{2} \quad$ : Konseling karier

(---) : Tanpa perlakuan/ intervensi

--- : Tanpa pretest

Alat ukur yang digunakan dalam penelitian ini adalah alat ukur yang dimodifikasi dari Hidayat (2014) dengan menambahkan aitem soal dan kemudian mengujicobakannya kepada sampel yang representatif. Hidayat (2014) menggunakan teori kematangan karier menurut John Crites bahwa kematangan karier terdiri dari dua dimensi, yaitu dimensi sikap dan kompetensi. Dimensi sikap terdiri dari lima aspek yakni keterlibatan dalam pengambilan keputusan, orientasi menuju kerja, konsep yang diperlukan dalam pengambilan keputusan, kemandirian dalam pengambilan keputusan, dan kesukaan terhadap jenisjenis pekerjaan. Reliabilitas Alpha Cronbach alat ukur ini sebesar 0,839. Menurut Devellis (2003), nilai Alpha Cronbach tersebut termasuk kategori sangat baik. Dimensi kompetensi terdiri dari lima aspek, yakni pemecahan masalah, perencanaan, informasi pekerjaan, penilaian diri dan pilihan tujuan. Reliabilitas Alpha Cronbach alat ukur ini sebesar 0,645.

Terdapat dua teknik analisis data yang digunakan. Pertama, Mann Whitney $U$ Test (uji beda dua kelompok) merupakan teknik analisis non parametrik untuk mengetahui perbedaan satu kelompok eksperimen dan satu kelompok kontrol, baik perbedaan skor screening, pre test, post test, maupun follow up (Kerlinger, 1990; Yamin \& Kurniawan, 2009; Trihendradi, 2005; Nisfiannor, 2009). Kedua, General Linear Model - Univariate untuk mengetahui perbedaan lebih dari tiga kelompok (Kerlinger, 1990; Yamin \& Kurniawan, 2009; Trihendradi, 2005; Nisfiannor, 2009). Pada penelitian ini, General Linear Model Univariate digunakan untuk mengetahui perbedaan skor post test dan follow up seluruh kelompok yang berjumlah enam kelompok.

\section{Hasil}

Berdasarkan uji beda berbagai analisis data pada pelatihan Reach Your Dreams didapatkan hasil sebagai berikut: a) Ada perbedaan tingkat sikap kematangan karier antara kelompok pelatihan "Reach Your Dreams" yang dikenai pretest dengan kelompok kontrol yang dikenai pretest $(\mathrm{Z}=$ -2,438 dengan Asyimp. Sig. 0,015 ( $\mathrm{p}<0,05))$. b) Ada perbedaan tingkat sikap kematangan karier kelompok pelatihan "Reach 
Your Dreams" yang tidak dikenai pretest dengan kelompok kontrol yang dikenai pretest $(Z=-2,374$ dengan Asyimp. Sig. $0,018(\mathrm{p}<0,05))$. c) Ada perbedaan tingkat sikap kematangan karier antara kelompok pelatihan "Reach Your Dreams" yang dikenai pretest dengan kelompok kontrol yang tidak dikenai pretest $(Z=-2,897$ dengan Asyimp. Sig. 0,004 ( $<<0,05))$. d) Ada perbedaan tingkat sikap kematangan karier antara kelompok pelatihan "Reach Your Dreams" yang tidak dikenai pretest dengan kelompok kontrol yang tidak dikenai pretest $(Z=-2,827$ dengan Asyimp. Sig. 0,005 $(\mathrm{p}<0,05))$.
Dari empat analisis di atas dapat dilihat bahwa hipotesis 1 terbukti yaitu pelatihan "Reach Your Dreams" efektif meningkatkan kematangan karier. Seluruh peserta pelatihan (yang dikenai pretest) mengalami peningkatan skor sikap kematangan karier. Hal ini dapat dilihat pada Gambar 1.

Kondisi yang sama ditunjukkan oleh kelompok yang tidak dikenai pretest yang mendapatkan pelatihan "Reach Your Dreams". Hal ini dapat dilihat pada Gambar 2.

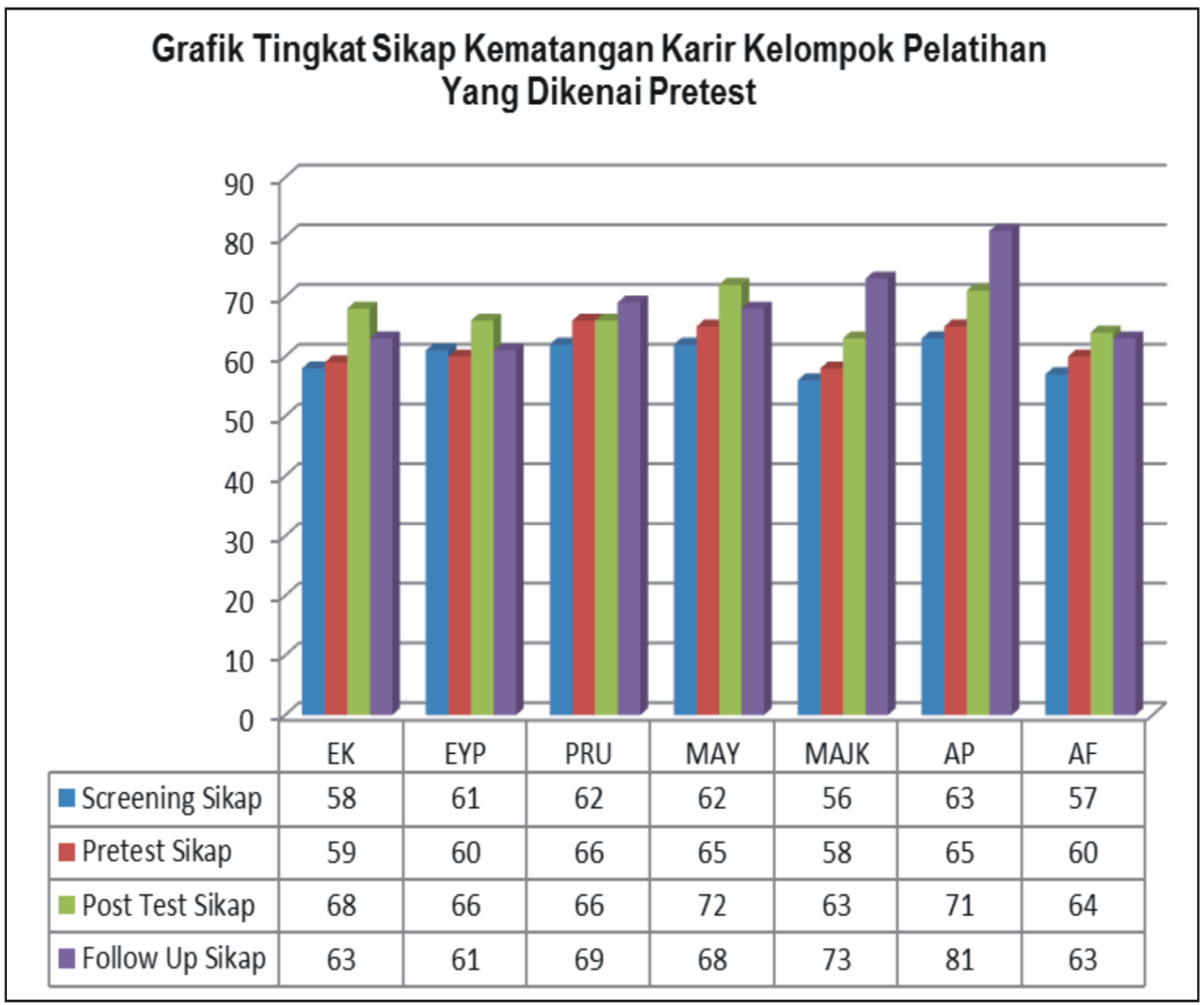

Gambar 1. Grafik Tingkat Kematangan Karier Kelompok Pelatihan yang Dikenai Pretest 


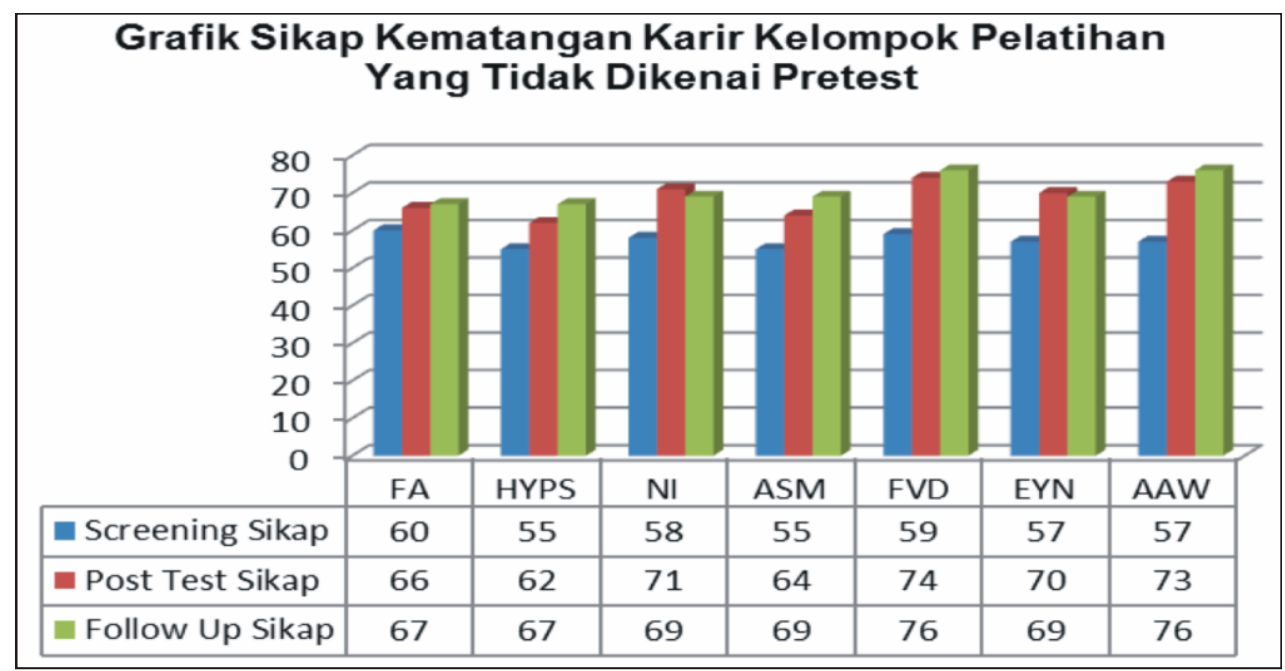

Gambar 2. Grafik Sikap Kematangan Karier Kelompok Pelatihan yang Tidak Dikenai Pretest

Uji beda selanjutnya adalah untuk mengetahui kematangan karier pada kelompok yang mendapatkan konseling karier. Hasil analisis adalah sebagai berikut: a) Ada perbedaan tingkat sikap kematangan karier antara kelompok konseling karier yang dikenai pretest dengan kelompok kontrol yang dikenai pretest $(\mathrm{Z}=$ -2,695 dengan Asyimp. Sig. 0,007 ( $<<0,05)$ ). b) Ada perbedaan tingkat sikap kematangan karier kelompok konseling karier yang tidak dikenai pretest dengan kelompok kontrol yang dikenai pretest $(Z=-2,246$ dengan Asyimp. Sig. 0,025 $(\mathrm{p}<0,05))$. c) Ada perbedaan tingkat sikap kematangan karier antara kelompok konseling karier yang dikenai pretest dengan kelompok kontrol yang tidak dikenai pretest $(\mathrm{Z}=$ 2,891 dengan Asyimp. Sig. 0,004 $(\mathrm{p}<0,05))$. d) Ada perbedaan tingkat sikap kematangan karier antara kelompok konseling karier yang tidak dikenai pretest dengan kelompok kontrol yang tidak dikenai pretest $(\mathrm{Z}=-2,251$ dengan Asyimp. Sig. 0,024 $(\mathrm{p}<0,05))$. e) Ada perbedaan tingkat sikap kematangan karier pada seluruh kelompok (F 3,662 dengan Sig. 0,009 ( $<<0,05)$ dan F 2,613 dengan Sig. 0,041 ( $<<0,05))$.

Dari beberapa analisis data di atas dapat disimpulkan bahwa hipotesis 2 terbukti yaitu konseling karier efektif meningkatkan kematangan karier. Secara lebih mendetail perubahan skor setiap subjek pada kelompok konseling yang dikenai pretest seperti terlihat pada Gambar 3. Demikian juga pada kelompok konseling karier yang tidak diberi pretest (Gambar 4).

Analisis selanjutnya untuk mengetahui perbedaan antara kelompok yang mendapat pelatihan Reach Your Dream dan kelompok yang mendapat konseling karier. Hasil analisis menunjukkan tidak ada perbedaan kematangan karier antara kelompok pelatihan yang dikenai pretest dengan kelompok konseling karier yang dikenai pretest $(Z=-1,410,0,158(p>0,05))$. Juga diperoleh hasil analisis bahwa tidak ada perbedaan kematangan karier antara kelompok pelatihan yang tidak dikenai pretest dengan kelompok konseling karier yang tidak dikenai pretest $(Z=-0,386,0,700$ $(p>0,05))$. Berdasarkan analisis data tersebut, hipotesis 3 terbukti bahwa tidak ada perbedaan kematangan karier antara kelompok yang diberikan pelatihan "Reach Your Dreams" dengan kelompok konseling karier. 


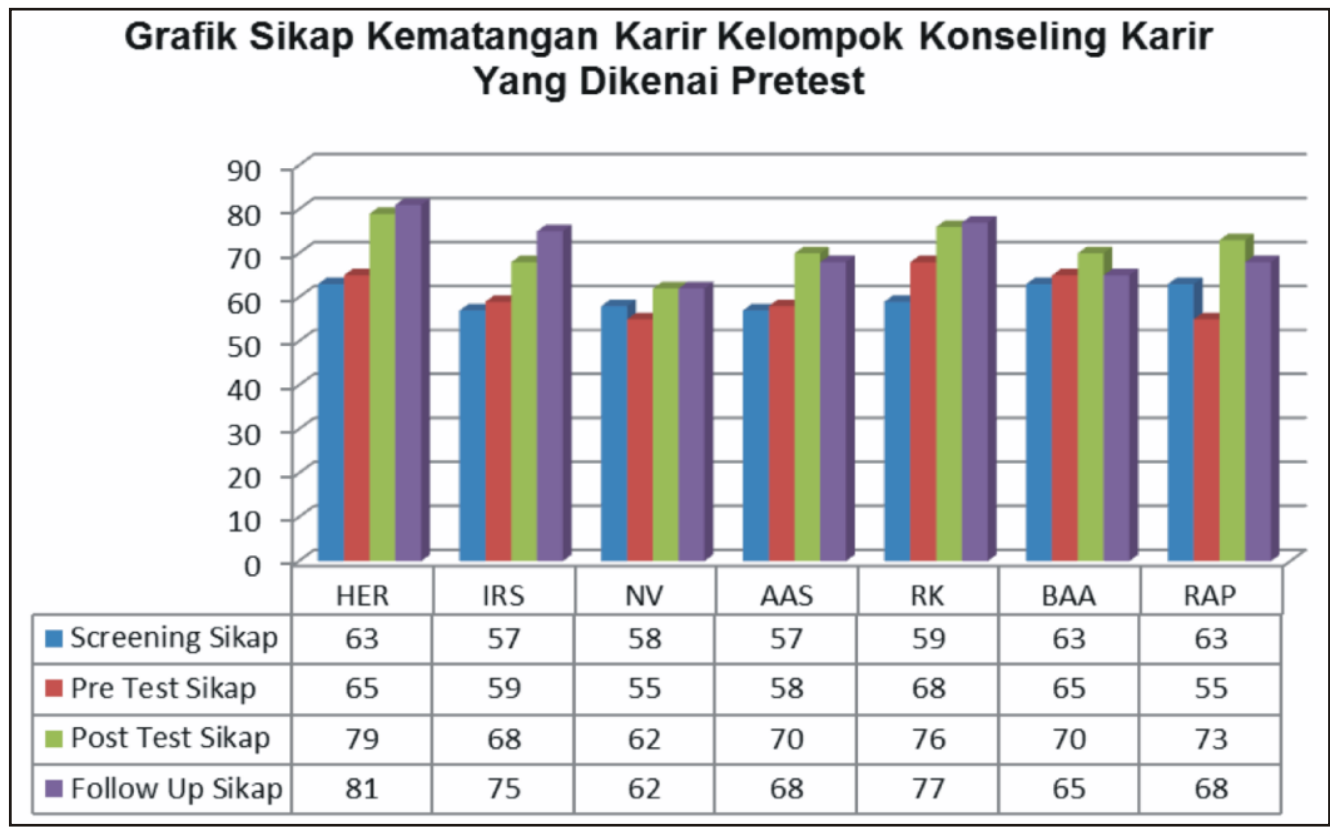

Gambar 3. Grafik Sikap Kematangan Karier Kelompok Konseling dengan Pretest

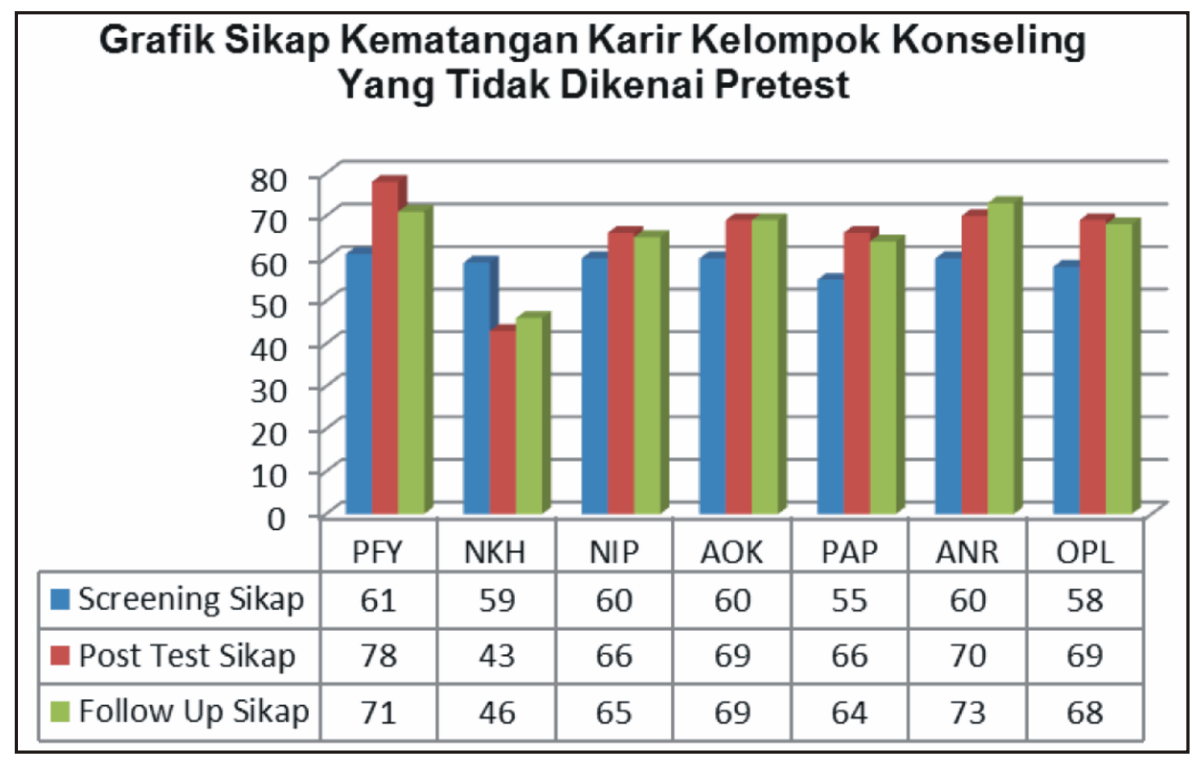

Gambar 4. Grafik Sikap Kematangan Karier Kelompok Konseling Tanpa Pretest

\section{Diskusi}

Dari hasil semua analisis di atas dapat disimpulkan bahwa pelatihan "Reach Your Dreams" dan konseling karier efektif meningkatkan kematangan karier. Hal ini ditunjukkan dengan adanya peningkatan skor sikap kematangan karier setelah mendapatkan pelatihan "Reach Your
Dreams" dan konseling karier. Bahkan sampai dengan follow up yang diadakan satu minggu setelah perlakuan, sikap kematangan karier masih tinggi. Kesimpulan lain adalah peningkatan sikap kematangan karier tersebut dikarenakan faktor intervensi (pelatihan dan konseling karier), bukan karena efek pretest dan faktor bias yang lain. 
Sebelum intervensi diberikan, terungkap dimensi kompetensi kematangan karier subjek penelitian juga tidak tinggi. Hal ini ditunjukkan pada kesulitan subjek penelitian dalam menganalisis diri dan mengerjakan lembar kerja analisis diri (aspek self appraisal), terbatasnya wawasan subjek penelitian tentang jurusan kuliah dan karier serta jenis perguruan tinggi (aspek occupational information), masih belum adanya perencanaan dalam meraih jurusan kuliah karena belum memiliki jurusan kuliah yang dipilih dan kesulitan subjek penelitian dalam membuat rencana jangka pendek maupun rencana jangka panjang (aspek planning), serta kesulitan subjek penelitian dalam membuat pemecahan masalah yang terkait pemilihan jurusan kuliah (aspek problem solving). Sikap-sikap subjek penelitian tersebut menunjukkan bahwa dimensi kompetensi kematangan karier subjek penelitian juga tidak tinggi.

Salah satu kelebihan pelatihan "Reach Your Dreams", selain pada tahapan yang terstruktur untuk membimbing subjek penelitian memilih jurusan yang sesuai (mulai dengan analisis diri, memberikan wawasan informasi jurusan dan karier, menentukan jurusan yang sesuai, dan merencanakan jadwal). Pelatihan "Reach Your Dreams" juga menampilkan symbolic model dalam bentuk video. Video tersebut berisi seseorang yang sukses dengan menuliskan rencana dan tujuannya. Dengan demikian, subjek penelitian akan lebih mudah mempraktekkan penyusunan jadwal dan target serta ada proses modeling (Corey, 2003).

Pelatihan "Reach Your Dreams" dapat meningkatkan kematangan karier karena adanya proses observational learning. Observational learning memiliki empat tahapan proses yaitu attention, rettention, production, dan motivation (Bandura, 1986).
Pada tahap attention, trainer menjelaskan tentang materi-materi perencanaan karier, tahapan-tahapan dalam perencanaan karier, contoh kasus mahasiswa yang salah memilih jurusan, dan pemutaran video. Proses ini dilakukan agar subjek bisa mendapatkan pengetahuan terlebih dahulu.

Kondisi awal yang sama juga diperlihatkan oleh empat belas peserta konseling karier. Rendahnya kematangan karier juga ditunjukkan dari skor hasil pretest dengan skala kematangan karier. Dengan demikian, kondisi awal peserta konseling karier sebelum mendapatkan konseling karier sama dengan kondisi awal peserta pelatihan "Reach Your Dreams" sebelum mendapatkan pelatihan tersebut.

Salah satu yang menjadi keunggulan dari konseling karier adalah pembahasan masalah yang bersifat grounded. Konselor menggali permasalahan rendahnya kematangan karier dengan berangkat dari ketidaktahuan peserta konseling akan jurusan kuliah dan karier karena peserta konseling belum memiliki gambaran jurusan kuliah yang akan dipilihnya kelak. Setelah itu, konselor menggali minat dan bakat peserta konseling. Kemudian konselor juga mengajak peserta konseling untuk mengkontekskan minat dan bakatnya tersebut ke dalam jurusan kuliah. Dengan demikian, peserta konseling mengalami insight dan memahami jurusan kuliah yang belum terpikirkan sebelumnya. Selain itu, konselor juga menanyakan mengenai dukungan orang tua dan keluarga terhadap pilihan jurusan kuliah. Sehingga jika ada kemungkinan orang tua kurang mendukung, konselor membekali beberapa strategi untuk mengkomunikasikan pilihan jurusan kuliah kepada orang tua dengan baik. Meskipun demikian, materi konseling karier tidak selengkap 
materi pelatihan "Reach Your Dreams" karena konseling karier memang dirancang berangkat dari permasalahan masing-masing peserta.

Wawasan jurusan kuliah dan karier terbukti mampu menambah pengetahuan subjek penelitian. Ketika pelatihan diberikan, semua subjek penelitian hanya memahami jurusan-jurusan yang sering diambil oleh banyak orang (misalkan hanya jurusan kedokteran, teknik, kependidikan). Selain itu, seluruh subjek penelitian juga masih belum memahami perbedaan fakultas dan jurusan atau program studi. Masih banyak subjek penelitian yang hanya memilih fakultas, belum mengerucut pada jurusan. Subjek penelitian kemudian diberikan modul mengenai macam-macam fakultas dan jurusan, beserta perguruan tinggi yang menyediakan jurusan tersebut dan juga prospek kerjanya. Dengan demikian, tahap wawasan program studi dan karier ini akan mampu meningkatkan aspek occupational information (yang dikemukakan oleh John O. Crites, 1974) dan aspek eksplorasi (yang dikemukakan oleh Super dalam Savickas, 2001).

Output dari pelatihan "Reach Your Dreams" dan konseling karier tersebut berupa subjek penelitian mampu menganalisis potensi diri dan mampu memilih jurusan yang sesuai dengan tipe kepribadian, minat, dan kemampuannya. Tidak hanya itu, subjek penelitian juga mampu menyusun rencana-rencana konkret untuk mencapai jurusan yang telah dipilihnya. Hal ini diwujudkan dalam bentuk subjek penelitian membuat rencana jangka pendek dan jangka panjang.

Hasil tersebut merupakan output dari tahapan menetapkan tujuan dan implementasi. Menetapkan tujuan, melibatkan proses pengambilan keputusan. Menurut Ginzberg (Fuhrman, 1990), pengambilan keputusan dalam memilih karier ini merupakan faktor proses kognitif seseorang. Pengambilan keputusan ini penting karena pengambilan keputusan biasanya mengevaluasi sedikitnya dua alternatif pilihan yang berbeda (Reed, 2000 \& Stenberg, 2008). Proses pengambilan keputusan ini dipengaruhi oleh beberapa faktor, salah satunya adalah faktor memori (Solso, Maclin, \& Maclin, 2008). Faktor memori dalam penelitian ini adalah memori berupa cara menganalisis diri, macam-macam jurusan dan fakultas, serta cara memilih jurusan. Dengan demikian, tahap penetapan karier dan perencanaan karier mampu meningkatkan aspek kompetensi (yang dikemukakan oleh John O. Crites, 1974) dan aspek pengambilan keputusan (yang dikemukakan oleh Super dalam Savickas, 2001).

Perbedaan mendasar dari intervensi pelatihan "Reach Your Dreams" dan konseling karier adalah terletak pada tekniknya. Jika pelatihan "Reach Your Dreams" memiliki tahapan yang rigid namun disampaikan dengan beragam metode (ceramah, diskusi, dan permainan), maka konseling karier tidak memiliki tahapan yang kaku. Konseling karier berlangsung sesuai permasalahan yang tergali dalam diri subjek penelitian dan berdasarkan kebutuhan yang diperlukan. Meskipun demikian, konseling karier tetap memiliki arah dan tujuan yang sama dengan pelatihan "Reach Your Dreams", yaitu meningkatkan sikap kematangan karier.

Penelitian ini berbeda dengan penelitian terdahulu. Penelitian terdahulu hanya menggunakan satu macam intervensi, misalkan penelitian Sirohi (2013) tentang bimbingan vokasional terhadap kematangan karier pada pelajar; Juwitaningrum (2013) tentang program bimbingan karier untuk meningkatkan kematangan karier 
siswa SMK; Hidayat (2014) mengenai efektivitas pelatihan PLANS terhadap kematangan karier; Ardana, Dharsana, \& Suranata (2014) tentang efektivitas konseling karier Holland dengan teknik modeling terhadap kematangan karier; dan Prastiwi (2015) mengenai peningkatan kematangan karier melalui Career Portofolio. Sepengetahuan peneliti, belum ada penelitian yang membandingkan dua macam intervensi kematangan karier. Dengan menggunakan dua intervensi dalam satu penelitian, maka akan diketahui intervensi yang paling efektif di antara beberapa intervensi kematangan karier tersebut. Selain itu, penelitian ini menggunakan desain eksperimen Solomon yang belum diterapkan oleh penelitian terdahulu. Seperti diketahui, desain eksperimen Solomon merupakan desain eksperimen yang paling ketat dan bisa mengetahui ada atau tidak adanya dampak pretest. Dengan demikian, bisa menjamin perubahan perilaku pascaintervensi tidak tercampuri faktor lain selain intervensi.

Terdapat keterbatasan dalam penelitian ini. Salah satunya adalah perbedaan hasil konseling karier antara kelompok yang dikenai pretest dengan kelompok yang tidak dikenai pretest. Konseling karier terbukti efektif dalam meningkatkan kematangan karier pada kelompok yang dikenai pretest. Sedangkan pada kelompok yang tidak dikenai pretest, tidak dapat meningkatkan kematangan karier secara signifikan. Hal ini disebabkan oleh beberapa faktor. Pertama, faktor kesiapan. Kelompok yang dikenai pretest memiliki kesiapan yang lebih tinggi daripada kelompok yang tidak dikenai pretest. Kelompok yang dikenai pretest mendapatkan pengarahan tindak lanjut dan tahapan penelitian setelah melaksanakan pretest. Dengan demikian subjek kelompok yang dikenai pretest memiliki kesiapan untuk mengungkapkan masalah mengenai kematangan karier yang rendah dan kebingungan memilih jurusan yang tinggi. Berbeda dengan kelompok konseling karier yang dikenai pretest. Kelompok yang tidak dikenai pretest mendapatkan pengarahan hanya ketika sebelum intervensi berlangsung. Sehingga, kesiapan dalam melaksanakan intervensi tidak setinggi kelompok konseling yang dikenai pretest.

\section{Kesimpulan}

Pelatihan "Reach Your Dreams" dan konseling karier efektif meningkatkan kematangan karier. Kematangan karier yang rendah dan sedang disebabkan oleh kurangnya wawasan jurusan kuliah dan karier, minimnya bimbingan karier dari guru dan orang tua, jurusan di SMA yang tidak sesuai dengan keinginan, pengaruh lingkungan, teman, dan orang tua. Pelatihan "Reach Your Dreams" lebih dapat meningkatkan kematangan karier dan lebih diminati daripada konseling karier karena beberapa hal.

\section{Saran}

Saran untuk peneliti selanjutnya adalah mencari subjek penelitian dengan karakteristik kematangan karier yang rendah. Penelitian ini hanya melibatkan peserta didik yang memiliki kematangan karier pada kategori "sedang". Juga disarankan memperbaiki alat ukur kompetensi kematangan karier dalam penelitian ini yang hanya memiliki kualitas reliabilitas Alpha Cronbach sebesar 0,645. Tingkat reliabilitas tersebut sudah cukup memenuhi standar alat ukur, namun tingkat kesulitannya rendah dan daya beda soal pun juga menjadi rendah.

Saran untuk pihak sekolah adalah sebaiknya pihak sekolah memilih tes 
masuk penjurusan yang lebih komprehensif sehingga pihak sekolah memiliki gambaran kematangan karier peserta didik yang lebih luas. Pihak sekolah juga sebaiknya mengadakan pendataan peserta didik yang jurusan di SMA berbeda dengan keinginan (minat) dan cita-cita.

Saran untuk peserta didik adalah menindaklanjuti konseling karier dan pelatihan dengan melaksanakan setiap jawaban yang ditulis dalam lembar kerja penugasan dan reflektif jurnal, misalkan rencana jangka pendek dan rencana jangka panjang, memaksimalkan potensi, dan menggali informasi jurusan dan karier lebih luas.

\section{Kepustakaan}

Ardana, I. S., Dharsana, K., \& Suranata, K. (2014). Penerapan konseling karier Holland dengan teknik modelling untuk meningkatkan kematangan karier siswa kelas X TKJ 1 SMK Negeri 3 Singaraja. E Journal Universitas Pendidikan Ganesha Jurusan Bimbingan Konseling, 2(1), 2014.

Ardiyanti, D., \& Alsa, A. (2015). Pelatihan "PLANS" untuk meningkatkan efikasi diri dalam pengambilan keputusan karier. Gadjah Mada Journal Of Professional Psychology, 1(1), 1-17, 2015.

Arthur, N., \& McMahon, M. (2005). Multicultural career counseling: Theoritical applications of the systems theory framework. The Career Development Quarterly, 53. doi: 10. 1002/j.21610045.2005.tb00991.x

Avati, P., \& Cahyadi, S. (2010). Rancangan program pelatihan meningkatkan kematangan karier mahasiswa psikologi UNPAD semester delapan. Penelitian Magister Profesi Psikologi Universitas Padjajaran Mayoring Psikologi Pendidikan.
Bandura, A. (1986). Social foundations of thought and action: A social cognitive theory. New Jersey: Prentice-Hall.

Brooks, L. (1990). Recent developments in theory building. Dalam D. Brown. \& L. Brooks. (Ed), Career choice and development: Applying contemporary theories to practice (2nd Edition). San Fransisco: Jossey-Bass.

Corey, G. (2003). Teori dan praktek konseling dan psikoterapi. Jakarta: Refika Aditama.

Cozby, P. C. (2009). Methods in behavioral research edisi ke-9. Yogyakarta: Pustaka Pelajar.

Crites, J. O. (1974). The career maturity inventory. New York: McGraw-Hill Book Company

Devellis, R. F. (2003). Scale development: Theory and application. California: Sage Publication, Inc.

Fuhrman, B. S. (1990). Adolescence adolscents 2nd edition. London: Scott Foresman/ Little, Brown Higher Education.

Hadi, S. (2015). Metodologi riset. Yogyakarta: Pustaka Pelajar.

Havighurst, R. J. (1984). Perkembangan manusia dan pendidikan. Jakarta: Jemmars.

Hidayat, M. (2014). Pengaruh pelatihan "PLANS" terhadap kematangan karier pada siswa SMA. (Tesis tidak dipublikasikan). Fakultas Psikologi Universitas Gadjah Mada, Yogyakarta.

Hurlock, E. E. (1980). Psikologi perkembangan suatu pendekatan rentang kehidupan. Jakarta: Erlangga.

Iffah, F. N. (2012). Pelatihan efikasi diri untuk meningkatkan kemampuan pengambilan keputusan karier siswa SMA. (Tesis tidak dipublikasikan). Fakultas 
Psikologi Universitas Muhammadiyah Surakarta.

Jaffe, D. T., \& Scott, C. D. (1991). Career development for empowerment in a changing work world, dalam Kummerow, J. M. (Ed.). New directions in career planning, hal. 33-59. Palo Alto, California: CPP Books.

Juwitaningrum, I. (2013). Program bimbingan karier untuk meningkatkan kematangan karier siswa SMK. Jurnal Bimbingan dan Konseling "PSIKOPEDAGOGIA", 2(2), 388-421, 2015. doi: 10.12928/psikopedagogia. v2i2.2580

Kerlinger, F. N. (1990). Asas-asas penelitian behavioral. Yogyakarta: Gadjah Mada University Press.

Koivisto, P. (2010). Preparing for working life: Effects of group counseling on adolescent's career development and mental health. Helsinki, Finland: Finnish Institute Of Occupational Health.

Latipun. (2010). Psikologi eksperimen. Malang: UMM Press.

Nisfiannor, M. (2009). Pendekatan statistika modern untuk ilmu sosial. Jakarta: Penerbit Salemba Humanika.

Prastiwi, A. R. (2015). Upaya meningkatkan kematangan karier melalui metode career portofolio pada siswa kelas X SMA di SMA N 1 Boyolali. Jurnal Bimbingan dan Konseling Fakultas Ilmu Pendidikan Universitas Negeri Yogyakarta, Edisi 9 Tahun ke-4 2015.

Reed, S. K. (2000). Cognition: Theory and applications fifth edition. USA: Wadsworth Thomson Learning.
Santrock, J. W. (2003). Adolescence, perkembangan remaja: Edisi keenam. Jakarta: Erlangga.

Savickas, M. L. (2001). A developmental perspective on vocational behavior. International Journal for Educational and Vocational Guidance, 49-57. doi: 10. 1023/A:1016916713523

Setyawati, C. L. (2005). Sikap siswa terhadap layanan bimbingan karier di SMA Tarsisius Vireta Tangerang. Jurnal Psikoedukasi 3(2) 2005, 112-127.

Sirohi, V. (2013). Vocational guidance and career maturity among secondary school students: An Indian experience. 1st Annual International Interdisciplinary Conference, AIIC 2013, 24-26 April (pp. 381-389). Azores, Portugal: Annual International Interdisciplinary Conference.

Solso, R. L., Maclin, O. H., \& Maclin, M. K. (2008). Psikologi kognitif edisi ke delapan. Jakarta: Penerbit Erlangga.

Stenberg, R. J. (2008). Psikologi kognitif edisi ke empat. Yogyakarta: Pustaka Pelajar.

Super, D. E., Crites, J. O., Hummel, R. C., Moser, H. P., Overstreet, P. L., \& Warnath, C. F. (1957). Vocational development: A framework for research. New York: Bureau of Publications, Teachers College, Columbia University.

Trihendradi, C. (2005). Step by step SPSS 13 analisis data statistika. Yogyakarta: Penerbit Andi.

Yamin, S., \& Kurniawan, H. (2009). SPSS complete, teknik analisis statistik terlengkap dengan software SPSS. Jakarta: Salemba Infotek. 